\title{
Truthmakers, Truthbearers and the Objectivity of Truth
}

\author{
Artur Rojszczak (Cracow) \\ Barry Smith (Buffalo/Leipzig)
}

The aim of this paper is to show that the account of objective truth taken for granted by logicians at least since the publication in 1933 of Tarski's "The Concept of Truth in Formalized Languages" arose out of a tradition of philosophical thinking initiated by Bolzano and Brentano. The paper shows more specifically that certain investigations of states of affairs and other objectual correlates of judging acts, investigations carried out by Austrian and Polish philosophers around the turn of the century, formed part of the background of views that led to standard current accounts of the objectivity of truth. ${ }^{1}$ It thus lends support to speculations on the role of Brentano and his heirs in contemporary logical philosophy advanced by Jan Wolenski in his masterpiece on the Logic and philosophy in the Lvov-Warsaw School of 1989.

\section{Bernard Bolzano: The Objective Truth of Sentences in Themselves}

The concept of the objectivity of truth as it is commonly understood in contemporary philosophy was initially formulated in 1837 by Bolzano in his Theory of Science. Bolzano there presents a Platonistic theory that can be seen as an anticipation of Frege's theory of thoughts or propositions. Bolzano, familiarly, draws a distinction between (1) the proposition or sentence in itself, and (2) the sentence as something that is thought, expressed, or uttered. The former is an ideal or abstract entity belonging to a special

\footnotetext{
${ }^{1}$ This paper develops ideas presented for the first time in our 2001 and (in press), which present a detailed history of the act-content-object distinction in relation to the concepts of truthmakers and truthbearers. The first stresses developments in our understanding of those special objects of judgments called states of affairs. The second concerns mainly the general development of theories of judgment at the turn of the last century. The present paper concerns especially the development of the concept of the objectivity of truth. It was completed after Artur Rojszczak's tragic death on 27 September 2001.
} 
logical realm; the latter belongs to the concrete realm of contingently existing thinking activities, or to the realm of speech or language.

Propositions exist (or better: they have whatever ontological status they have) outside or beyond the realm of what exists in space and time. A proposition can be conceived as the ideal content of an assertion to the effect that something is or is not the case. This content is what it is regardless of whether or not somebody has put any corresponding assertion into words, and regardless of whether or not it has been thought. ${ }^{2}$ Platonistic theories along these lines played an influential role in the subsequent history of philosophy, for instance in the theories of Lotze, Stout, and above all Frege. However it is only through the intermediation of Twardowski and Husserl, and of certain other students of Brentano in Vienna, that a direct influence of Bolzano can be detected.

For Bolzano, truth and falsehood are timeless properties of propositions. Every proposition is either true or false. The property of having a truth-value cannot, however, be used as the definition of what it is to be a proposition. ${ }^{3}$ This is because propositions form the content also of our mental acts of judgment, and our speech acts of assertion, so that the latter, too, can be called true or false in an extended sense.

Like Platonistic theories in general, Bolzano's theory is especially well-designed to serve as a basis for a defense of the objectivity of truth. Every truth is mindindependent in the sense that it obtains independently of whether it is ever thought or recognized. Every truth is absolute in the sense that it does not depend on the context in which it is judged or asserted. ${ }^{4}$

As concerns the logical form of propositions - and thus of judgments - Bolzano conceives all propositions as having three parts: a subject idea, a predicate idea, and the concept of having, so that each proposition can be canonically represented by means of the expression "A has b". Bolzano's views thereby fall into line with the so-called combination theory of judgment, the standard position in the nineteenth century. This theory considers the activity of judging as a process of combining or separating certain mental units called 'concepts', 'presentations', or 'ideas'. Judgments are divided into two

\footnotetext{
${ }^{2}$ Bolzano 1837, par. 19 (1972, pp. 20-21).

${ }^{3}$ Bolzano 1837, par. 23, 125.

${ }^{4}$ Bolzano 1837, par. 25.

${ }^{5}$ Bolzano 1937, par. 127 (1972, p. 173)
} 
sorts: the positive, which involve a putting together of concepts; and the negative, which involve a separating of concepts, usually a pair consisting of subject and predicate, related to each other by means of a copula. Theories of this sort, which have obvious roots in Aristotle, tend to consider traditional syllogistic as an adequate account of the logic of judging.

Although he accepted this combination theory, Bolzano nonetheless represents a somewhat exceptional case, since he stood opposed to the immanentistic view of judgment which, as a result of the dominance, especially among German philosophers, of different forms of Idealism, had established itself in the nineteenth century. According to this immanentistic view, the process of judging is to be understood entirely from the perspective of what takes place within the mind or consciousness of the judging subject. Indeed, German philosophers of the time held that even the objects of knowledge are located in the mind of the knowing subject. Combination theories in the idealist spirit were developed in Germany by, among others, Gustav Biedermann, Franz Biese, Eduard Erdmann, Kuno Fisher, Ernst Friedrich, Karl Prantl, and Hermann Schwarz, and they were embraced in England for example by the early G. E. Moore.

One of the problems with immanentistic versions of the combination theory turns precisely on the notion of truth. In the years prior to 1900 a number of philosophers realized that, if we are properly to speak of truth as a value, then it is necessary to recognize some objective standard that is independent of, and thus transcendent to, the judging subject. Thus they challenged the assumption that conceptual combination provides all that is needed to account for the nature of judgment, drawing on Aristotle's thesis, in Categories (14b) and Metaphysics (1051b), to the effect that a combination of concepts may reflect a parallel combination of objects in the world. This thesis has the implication that the phenomenon of judgment can be properly understood only by taking ontology into account. Aristotelian theories of judgment based on doctrines of transcendent correlates of acts of judgment on the side of objects in the world had been developed already by Abelard (e.g. in his Logica Ingredientibus) and by Aquinas (De Veritate 1, 2). They can be found in the seventeenth century in Locke (Essay IV, V) and also in Leibniz, for example in his experiments in the direction of a combinatorial logic in the Nouveaux Essais, IV. 5; but the pursuit of such theories waned with the waxing of the 
influence of Kant. Bolzano then marks the beginning of a new phase of thinking about judgment, in which it is recognized that even if judging involves a combination of concepts, the truth of a judgment must involve in addition something objective against which this truth is to be measured.

Bolzano himself suggested that it is propositions or sentences in themselves that serve as the objective standard of the truth of our judgments. But there are three obvious problems with this account. The first is what we may call the problem of cognitive access. How can we be acquainted with objects that are not in space and time - with ideal entities whose existence does not depend in any way on our cognition? What is the relation between a particular act of judging and such abstract entities? This is what Michael Dummett, in his Origins of Analytic Philosophy, refers to as the "linkage" problem.

The second problem turns on Bolzano's assumption to the effect that there are sentences in themselves relating to every actual and possible situation in the world and that it is in virtue of standing in relation to such sentences in themselves that we can judge and express our beliefs about the real world. This means, however, that there obtain timeless sentences in themselves about Julius Caesar and Sherlock Holmes, about the entire pantheon of Aztec and Inca gods, about the number of coins and the number of molecules in every trouser pocket at every instant in the history of the universe, and about all manner of even the most contrived and ephemeral actual and possible combinations of objects which our minds (or other, quite alien minds) might conceive. Even leaving aside all problems of determinism and predestination, this seems to involve also the ontological defect of a massive multiplication of reality. Indeed it turns out that the history of the universe is instantiated twice: once timelessly, in the form of sentences in themselves in Bolzano's Platonic realm, and then again in the form of actual events, some of which are experienced by cognitive, judging subjects like ourselves.

The third problem turns on the fact that propositions in Bolzanian heaven seem not, after all, to provide in and of themselves the required sort of standard of truth. For all propositions, independently of whether they are true or false, are cut of one cloth. Thus 
we require some supplementary account of why it is that some of them should bear the mark of truth, while others bear the mark of falsehood.

\section{Hermann Lotze and Julius Bergmann: The Concept of the Sachverhalt}

We shall use the term 'truthbearer' in what follows to designate an entity of which truth or falsity can be predicated attributively. More loosely, it is any entity which is in the market for being true or false. The term 'truthmaker' shall designate an entity in virtue of which a truthbearer is indeed true. The task of finding an account of the relation between propositions and the real world about which we empirically judge is then more briefly described as the task of establishing the relation between truthbearers and truthmakers. ${ }^{6}$ Another expression used to refer to the truthmaking objective correlates of propositions is the term 'Sachverhalt', now generally translated as 'state of affairs'. The term Sachverhalt is derived from phrases in standard German usage like 'wie die Sachen sich zueinander verhalten', which means: how things stand, or relate towards, or behave in relation to each other. The term occurs in passing in Hermann Lotze's Logic of 1874, where Lotze defends the view that there are special objects of judgment. He introduces his treatment of judgment by contrasting relations between presentations on the one hand and relations between things on the other. It is only 'because one already presupposes such a relation between things as obtaining,' Lotze writes, 'that one can picture it in a sentence (in einem Satz abbilden)'.

According to Julius Bergmann, who first used the term Sachverhalt systematically in his General Logic of 1879, knowledge can be defined as that sort of thinking 'whose thought content is in harmony with the Sachverhalt, and is therefore true. ${ }^{7}$ In the hands of Bergmann, therefore, the Sachverhalt serves as the objective component to which the judgment must correspond in order to have the value true.

\footnotetext{
${ }^{6}$ For more on the notion of truthbearer and its history see Nuchelmans 1973; on the notion of truthmaker see Mulligan, Simons and Smith 1984, and Smith 1999.

${ }^{7}$ Bergmann 1879, pp. 2-5, 19, 38
} 
Lotze's idea to the effect that special kinds of objects can serve as the targets of judging acts was taken over not only by Bergmann but also by Frege, who attended some of Lotze's lectures in Göttingen, where Frege received his doctoral degree. Frege, we might say, took the conceptual complex of the idealists and made out of it a Platonic object, called a 'thought' or 'Gedanke'. Frege's development of a Platonistic view bears traces also of another Lotzean idea, that of Geltung or validity. ${ }^{8}$

Lotzean ideas on the objects of judgment were developed also in England through the influence of James Ward, who studied under Lotze after the latter's appointment in Göttingen in 1844. George Frederick Stout, too, began to pay attention to the psychology of act and content which was being developed in Austria and Germany, resulting in his Analytic Psychology of 1896. It was Stout who introduced the English-speaking world to the idea of a theory of special objects of judgment. ${ }^{9}$

\section{Franz Brentano: Truth and Intentionality}

It is above all Franz Brentano who is responsible for the development of the psychology of act and content which influenced Stout and others. After first embracing a doctrine of judgment which accepted also certain sorts of ideal entities or entia rationis at least in some respects analogous to Bolzano's propositions in themselves, he moved in his later writings to a resolutely immanentistic approach to the theory of judgment and cognition. ${ }^{10}$ Brentano's pupils and the pupils of his pupils were however inspired by his work on the topic of intentionality ${ }^{11}$ and also by his break from the combination theory of judgment in ways which led Brentanian ideas to play a still crucial role in developing the notion of objective truth along the lines partially anticipated by Bolzano.

It is intentionality which spans the gulf between act and object. Brentano's revival of the concept of intentionality thus helped to entrench theories of judging acts of a sort

\footnotetext{
${ }^{8}$ See Pfeil 1914, Kreiser 2001.

${ }^{9}$ See van der Schaar 1991.

${ }^{10}$ See Smith 1994, Chapter 2.

${ }^{11}$ Brentano 1874/1924 (1973, pp. 77-100, especially pp. 88-89).
} 
which take seriously the idea that there are correlates of judgment on the side of objects in the world.

Whereas for Bolzano truth is centrally a matter of what holds in the ideal realm of sentences in themselves, it is for Brentano - or at least for the later Brentano who will here primarily concern us - a matter of special types of judging acts. The psychological description and classification of judgments in all their modes is thus for him a necessary precursor not only to the theory of truth but also to the theory of knowledge. Brentano distinguishes three basic types of mental or, as we can also say, intentional phenomena: presentations, judgments, and phenomena of love and hate. Each of these types is determined by its own characteristic intentional directedness to an object, whereby it is left unspecified whether this object exists.

A presentation is any act in which the subject is conscious of some object without taking up any position with regard to it. 'Presenting', Brentano tells us, is just the 'appearing' (Erscheinung) of an object. Presenting may be either intuitive or conceptual. That is, we can have an object before our mind either in sensory experience (and in variant forms thereof in imagination or memory) or in concept. A simple presentation is for example the appearing of a red sensum; a complex presentation the appearing of an array of differently colored squares. ${ }^{12}$

In most normal mental experiences, however, we do not merely allow an object to appear; rather we take some stand in relation to it. The two most basic ways in which we take such a stand are what Brentano calls 'acceptance' and 'rejection'. To accept an object is simply to believe that it exists; to reject an object is to believe that it does not exist (for example when I come to recognize that there is no money in my pocket). Brentano now identifies judgment with the presence of such positive or negative belief. His break with the combination theory - and indeed his logical difference with Bolzano, Frege, and the contemporary mainstream of thinking about judgment and assertion - is rooted in his theory of acceptance and rejection, for this amounts to a special treatment of the copula, and of what makes a judgment positive or negative. It is what amounts to a

\footnotetext{
${ }^{12}$ Brentano 1874/1924 (1973, pp. 79f., 88f.)
} 
dual copula that determines, in Brentano's eyes, the very essence of judgment. For Brentano, acceptance and rejection are specific processes of consciousness, and both are pointed, through presentation, in the direction of objects. They are thus to be distinguished from what analytic philosophers later called 'propositional attitudes', whose target is not an object but a proposition. Brentano, however, has no room in his later ontology for abstract entities of this sort.

A judgment, for Brentano, is in sum either the belief or the disbelief in the existence of an object, and this means that Brentano embraces what we can call an existential theory of judgment. All judgments have one or other of the two canonical forms: 'A is' or 'A is not.' The judgment expressed in the sentence 'Franz sees a beautiful autumn leaf' ought, according to Brentano's existential theory, to be expressed as follows: 'The seen-by-Franz-beautiful-autumn-leaf is.' The judgment expressed in the sentence 'Philosophy is not a science' should be transformed into: 'Philosophy-as-science is not' or 'scientific-philosophy is not'. The universal judgment expressed in the sentence: 'All people are mortal' should be represented as: 'There are no immortal people' or 'Immortal-people are not'. Judgments can be further classified into probable/certain, evident/not evident and a priori/a posteriori. Brentano holds that each of these distinctions represents an actual psychological difference in the acts of judgment themselves. As we shall see, the same cannot be said about the classification of judgments into true and false.

In the nineteenth century, logic was seen primarily as a theory of thinking. It fell within what we would today see as the province of psychology (and this gave rise to the crisis of psychologism, which was brought to a head above all with the publication of the first volume of Husserl's Logical Investigations in 1900). Like almost all his contemporaries, Brentano follows Aristotle in holding that a judgment's being brought to overt expression in language is a secondary phenomenon - it is the internal act of judgment itself that is primary. Brentano's theory does, however, draw out the linguistic implications which follow from this psychological theory of judgment. Acts of presentation (the counterparts of concepts as these appeared in the framework of the standard combination theory) are expressed by names as these occur in a natural language 
such as English or German. Acts of judging are expressed by more complex linguistic expressions - called sentences - whose meanings depend on the meanings of their constituent simple or complex names, the latter being determined by how sentences appear when translated into the canonical existential form.

Brentano can against this background seek linguistic justification for his psychological theory of judgment. He discusses, for example, the phenomenon of subjectless sentences, especially the meteorologica ('It's raining', 'It's snowing') and other families of examples studied by Miklosich and other linguists, judgments of a type which it is hard to treat within the terms of the standard (subject-predicate-copula based) combination theories, but which fit very nicely into Brentano's existential theory of judgment. ${ }^{13}$ Another example crucial to Brentano's analysis of truth and falsehood is the distinction between categorematic and syncategorematic expressions. Syncategorematica are words that refer not in and of themselves but rather only in association with other words within some context. 'True' is according to Brentano syncategorematic in all its grammatical variants. This means that there is nothing real in virtue of which a true judgment differs from a judgment simpliciter (as there is nothing real in virtue of which an existing dollar differs from a dollar). It means also that there is no psychological property of judging acts to which the predicate 'true' refers. (Brentano's successors applied this same kind of analysis to yield similarly deflationary analysis of words like 'being' and 'nothing'.)

\section{Truth and Subjectivity}

Judgment, for Brentano, is a subjective phenomenon. Judgments are mental episodes of individual judging subjects. This view blocks any account of truth and falsity as timeless properties along Bolzanian lines - and indeed, as already mentioned, Brentano has no room in his ontology for abstract entities of a Bolzanian sort. How, then, can he tie the subjective realm of mental acts of judgment to the objective realm of truth?

One solution within his general framework would lie in some appeal to the traditional conception of truth as correspondence. Brentano, however, came to reject this

${ }^{13}$ Brentano 1889 (1969, pp. 98-108). 
idea - among other reasons because the correspondence theory does not yield a criterion of truth. Brentano was convinced that a theory of truth must also solve the problem of knowledge, which is to say that it should provide a means by which we can intelligibly pick out truths from falsehoods. He believed himself to have found such a criterion in relation to what was for him a large and important class of judging acts pertaining to the sphere of what he called inner perception. ${ }^{14}$ Hence Brentano moved to the so-called 'epistemological conception of truth', sometimes also called the evidence theory of truth, a move supported also by his view according to which the terms 'true' and 'false' are syncategoremata. While there are no properties of judging acts to which the latter terms could refer, there are properties of such acts which amount to their being evident. Brentano's treatment of the concept of evidence then constitutes an important Cartesian strain in his thinking, which runs in parallel with certain Aristotelian aspects of the Brentanian philosophy. How is it that an empirical subject can come to know objective truth? This question has no answer in the case of Bolzano (or Frege). Brentano's answer is as follows. He divides all judgments into judgments of necessity and judgments of fact. The latter he divides further into judgments of inner and of outer perception. A judgment is judged with evidence, as Brentano conceives matters, only when there is what he calls an 'identity' of the judger and that which is judged. The experience of such an identity is illustrated in Descartes' cogito: I think, therefore I know (judge with evidence) that I am thinking. The validity of this inference is so fundamental that it cannot be explained further, but must simply be experienced. ${ }^{15}$ While the identity of judger and judged, of the ego cogito with its cogitations, is ruled out for judgments of outer perception, it is manifested in all judgments of inner perception. 'Inner perception is evident, indeed always evident: what appears to us in inner consciousness is actually so, as it appears. ${ }^{, 16}$

Evidence is manifested also by judgments of necessity, which Brentano also calls 'axioms', and which are illustrated by judgments such as: a round square does not exist, a sound is not a color, a judgment is not a presentation. Brentano holds that such judgments have as their objects conceptual relations. Their truth flows a priori from the

\footnotetext{
${ }^{14}$ Brentano 1930.

${ }^{15}$ Brentano 1928, par. 2 (1981, p.4).

${ }^{16}$ Brentano 1956, p. 15.
} 
corresponding concepts. ${ }^{17}$ They are a priori in the sense that they do not rely on perception or on any judgments of fact.

According to Brentano we can judge truly about the external world. He insists, however, that such judgments must remain a matter of hunch or guesswork. They do not belong to knowledge in the strict sense. Truth, for Brentano, is then subjective in the sense that it is a real character of our judgments which exists only where there is this experience of evidence. But it can also be seen as objective in that the experience of evidence can be gained only with respect to a certain class of judgments - namely the true ones - and what can and what cannot belong to this class is fixed independently of the judging subject. ${ }^{18}$

The central problem with Brentano's understanding of truth is that it leaves us with no account of how axioms in general and logical truths in particular can be valid atemporally. Brentano, we will recall, has (at those later phases in his career which here concern us) no room in his ontology for abstract entities, that is for extra-temporal entia rationis such as ideal propositions or ideal concepts of the sort accepted by Bolzano. Thus he has no ideal realm of Platonic objects serving to guarantee the absoluteness (atemporality) of truths. This is related, of course, to the charge of psychologism, which was raised against Brentano in the wake of Husserl's Logical Investigations. Brentano's answer to this charge rested on the assertion that the objectivity of logic is to be justified by evidence in just the way in which evidence guarantees the objectivity of the empirical truths of inner perception. But the evidence-based concept of truth relates always only to single cognitive acts and thus always only to a single judging subject. How, on this basis, are we to explain the fact that logic is a common possession of all thinkers, and that it gives rise in timeless fashion to a shared system of normative rules for thinking and reasoning?

A further group of problems for Brentano turns on the question of the objectual correlates of mental activities and especially of judging acts. If judging is the acceptance or rejection of something, then we still need to determine what this something is that is

\footnotetext{
${ }^{17}$ Brentano 1956, pp. 141 ff, 162-165, 173; Brentano 1933 (1981, p. 71).

${ }^{18}$ On Brentano's theory of truth see Brentano 1930, Baumgartner 1987, Rojszczak 1994.
} 
accepted or rejected, even if Brentano does not want to rely on the correspondence theory of truth. That which is accepted or rejected Brentano calls the judgment's matter. The latter is on Brentano's account the object of the underlying act of presentation. The mode in which it is judged - acceptance or rejection - he calls the quality of the judgment. To understand these terms we need to look once again at Brentano's concept of intentionality. Are we to give a relational or a non-relational account of the expression 'being directed towards an object'? The relational interpretation of intentionality sees all mental acts as directed towards objects as their transcendent targets. That this is a problematic interpretation can be seen by reflecting on the acts involved in reading fiction, or on acts which rest on mistaken presuppositions of existence. The thesis that all mental acts are directed towards objects in the relational sense, to objects external to the mind, seems to be clearly false - unless, with Meinong, we admit modes of being of objects in addition to that of existence or reality. ${ }^{19}$

Brentano himself preferred a non-relational (or adverbial) interpretation of intentionality. On this view, intentionality is a one-place property of mental acts; it is the property of being directed in this or that specific way. When Brentano talks of directedness towards an object, he is thus not referring to any putative transcendent targets (though a thesis along these lines has repeatedly been attributed to him $^{20}$ ) Rather, he is talking of directedness towards what is in the mind. Each object of thought resides in - is 'immanent to' - the mental acts of some real substance (a thinker). ${ }^{21}$ The act of thought is a real event or process; the object of thought exists only in virtue of the fact that the act which thinks it has being. The object of thought is in its nature something non-real.

How, on this basis, is Brentano to deal with negative existential judgments such as 'God does not exist'? The latter seems both to have and to lack an object. As we shall see, it was as part of an attempt to solve these difficulties that Brentano's immediate successors began to reconsider his own move to a position according to which acts of

\footnotetext{
${ }^{19}$ Meinong 1899.

${ }^{20}$ See for example Dummett's Origins of Analytical Philosophy, especially chapter 5 on 'The Legacy of Brentano'.

${ }^{21}$ Brentano 1930 (1961, p. 27), Brentano 1874/1924 (1973, p. 88-89), Brentano 1982, esp. pp. 10-27.
} 
judgment take their objects from underlying acts of presentation, and to affirm instead theories of truth which award a central place to transcendant correlates of judging acts and they thereby opened the door to a revivified conception of truth as correspondence.

Brentano's successors addressed the problem of the objectivity of truth in two ways. On the one hand via fine-grained investigations of the mental side of the acts of judgment, and of the relation of such acts of judgment to uses of language. And on the other hand via investigations of the objectual correlates of (true) judgments in the world. The former - investigations of truthbearers - led to a movement from psychology to semantics. The latter - investigations of truthmakers - led to a movement from psychology to ontology - a movement which led to the postulation of special objects of judging acts. Both movements would culminate in the formulation of constraints which linguistic entities must satisfy if they are to be about objects in the world - constraints nowadays standardly formulated in terms of Tarski's notion of satisfaction. But before all of this could come about one more step was needed.

\section{Stumpf on Content and Object of Judgments}

Between 1874 and 1904 Brentano strove to develop a theory of intentionality as a genuine relation between the subject and an immanent object. In this period he allowed not only the nominal correlates of propositional acts but also genuinely propositional correlates of acts of judgment, including both immanent and transcendent correlates. Brentano's disciples learned about these matters from his lectures, and above all from the still unpublished Logic lecture from the 1880s (Manuskript EL80). We find traces of the view also in the essay "Über den Begriff der Wahrheit" of $1889 .^{22}$

In the course of time, however, Brentano notoriously abandoned all such doctrines, rejecting all entia rationis and identifying the ontological correlates of judging acts with the immanent objects of the underlying acts of presentation. Some of his immediate followers, however, inspired at least to some degree by Bolzano and by Lotze, remained faithful to the idea that there are special correlates of acts of judgment - entities which would be categorically distinct from the correlates of acts of presentation. In 1888

${ }^{22}$ For details see Chrudzimski 2001(pp. 62-66 and 80-83), 2001a (pp. 175-180). 
Stumpf employed the term 'Sachverhalt' to refer to such special judgment correlates, and he thereby established a tradition of usage for the term which would prove more influential than that of Lotze or Bergmann. The relevant passage appears in Stumpf's logic lectures of 1888 :

From the matter of the judgment we distinguish its content, the Sachverhalt that is expressed in the judgment. For example 'God is' has for its matter God, for its content: the existence of God. 'There is no God' has the same matter but its content is: non-existence of God. (MS Q 13, p. 4)

The Sachverhalt is that specific content of judgment 'which is to be distinguished from the content of a presentation (the matter) and is expressed linguistically in "that-clauses" or in substantivized infinitives. ${ }^{23}$

Sachverhalte or states of affairs are assigned by Stumpf to the special category of what he calls 'formations', a category which he contrasted with the category of what he calls functions, which embraces mental acts and related events and processes. Stumpf assigns not only concepts and states of affairs to the category of formations, but also Gestalt qualities, values, and sets or classes in the mathematical sense. He compares formations to constellations of stars, entities which we pretend to find in the heavens above, but which are in fact (as Stumpf conceives them) creatures of our mental world. Formations in general are for Stumpf not entities that exist in and of themselves somewhere in the world. Rather they are, like the objects of acts of presentation, immanent contents of our mental acts. (To this degree, therefore, Stumpf remained faithful to the immanentism of his master Brentano.) Formations exist only in the context of the living being of the mind'. ${ }^{24}$

\section{Twardowski on the Content and Object of Judgments}

It was Kazimierz Twardowski, of all the students of Brentano, who first freed himself from the immanentistic position. In his On the Content and Object of Presentation, published in 1894, Twardowski develops a crucial distinction between the contents of presenting acts on the one hand, and their objects, on the other, with only the former

\footnotetext{
${ }^{23}$ Stumpf 1907, pp. 29f., and compare Smith 1992.

${ }^{24}$ Stumpf 1907, p. 11, 32. Stumpf 1907a, p. 34.
} 
being immanent to the mind. Twardowski begins his investigation with an analysis of the opposition between 'presentation' (Vorstellung) on the one hand, and 'that which is presented' (das Vorgestellte), on the other. Both terms had been used by earlier philosophers, including Brentano and Stumpf, in ambiguous ways. The first referred sometimes to an act or activity of presenting, sometimes to the content or immanent object of this act. The second referred sometimes to this immanent object (roughly: to an image of the real thing), sometimes to this real thing itself as it exists in mindindependent reality. To prevent this confusion we need to draw a sharp line between contents and objects. The two are distinguished first of all by the fact that there are properties which we ascribe to the object that are not properties of the content - my image of a red nose is not itself red - and by the fact that the object can be real or not real, whereas the content, as Twardowski conceives it, belongs in every case to the realm of abstract entities. Contents are thus comparable to senses in the Fregean philosophy. We can, Twardowski held, make true judgments even about non-existent objects, as for example when we judge truly that Pegasus has wings.

Brentano's thesis of intentionality amounts to the thesis that what is characteristic of mental phenomena is a relation to an object. Twardowski takes this thesis literally and he thus embraces a view now more commonly associated with Meinong, according to which every mental act has some sort of object. Intentionality is a relation in the fullest sense of the word. Twardowski defines the content of an act of presentation precisely in relational terms: it is the 'link between the act and the object of a presentation by means of which an act intends this particular and no other object. ${ }^{25}$ The object of such an act Twardowski characterizes as follows:

Everything that is presented through a presentation, that is affirmed or denied through a judgment, that is desired or detested through an emotion, we call an object. Objects are either real or not real; they are either possible or impossible; they exist or do not exist. What is common to them all is that they are or they can be the object $\ldots$ of mental acts, that their linguistic designation is the name. . . Everything which is in the widest sense 'something' is called 'object', first of all

${ }^{25}$ Twardowski 1894 (1972 p. 28-29); see also Wolenski 1998/99. 
in regard to a subject, but then also regardless of this relationship. (Twardowski 1894 (1972, p. 37))

Twardowski, as we see, attempts a linguistic explication of results he has obtained from his work on the level of psychology. In this he follows his teacher Brentano, as he follows Brentano also in embracing a view according to which, while there is no strong parallelism between thinking and language, linguistic analysis can still help in the diagnosis of the relations obtaining in our mental life. It is above all Brentano's opposition between two types of adjectives, the determining, and the modifying, ${ }^{26}$ upon which Twardowski draws most heavily:

An adjective is called determining, if it completes, enlarges - be it in a positive or in a negative direction - the meaning of the expression to which it is attached. A determination is modifying if it completely changes the original meaning of the name to which it is attached. (Twardowski 1894 (1972, p.11))

'Firm' in 'firm handshake' is used determinatively; 'decline' in 'declined handshake' is used in a modifying way. It is in terms of this distinction between two different types of adjectives that Twardowski formulates his analysis of confusions in earlier philosopher's uses of terms like 'presentation'. Thus he points out that the adjective 'presented' can function in a two-fold manner, as a determining or a modifying adjective. It occurs as determining when the expression 'the presented landscape' refers to a landscape which is the object of some mental act. Otherwise, however, 'presented' (like 'imagined', 'thought' or 'supposed') functions in a modifying way - it modifies the meaning of the word 'landscape'. This emphasis on the interplay of linguistic and psychological features of judgment will remain a distinguishing feature of Twardowski's later work as well as of the work of his Polish students.

A very important example of this contrast between determining and modifying adjectives is illustrated in our usage of the terms 'true' and 'false'. In expressions like 'false friend' and 'false gold', the adjective 'false' functions in a modifying way. As predicated of beliefs or judgments, however, Twardowski (and in this he differs from his teacher Brentano) holds that both terms function as determinators. The bearers of truth and falsity for Twardowski are judgments (which in 1894 he still understood as

${ }^{26}$ Brentano 1874, vol. II, pp. $62 \mathrm{ff}$. 
psychological occurrences). The latter can be called 'truths' and 'falsehoods', and when these terms are used literally they always mean a judging act which corresponds or fails to correspond to the things as they are in the world. In fact, the proper use of these terms is in their adjectival (determining) form - and in stating this view Twardowski anticipated one of the standard assumptions of contemporary theories of truth, namely that the predicates 'true' and 'false' (like 'identity' and 'existence') are univocal determinators, which means that they do not change their meaning from context to context or within a given theory.

In On the Content and Object of Presentations Twardowski sees the act of judgment as having a special content of its own, but no special object. The content of a judgment is thus still the existence of the object of the relevant underlying presentation. Three years later, however, in a letter to Meinong, Twardowski suggests that one should recognize in addition to the judgment-content also a special object of the judging act. ${ }^{27}$ Once the existence of a special judgment object has been granted in this manner, a range of different types of investigation of truthbearers and truthmakers becomes possible, the fruits of which we see in the work of Meinong, Ehrenfels, Husserl, and other successors of Brentano around the turn of the century. And Twardowski's own special interest in the relation of judgment to its linguistic expressions initiated a tradition in Poland which, as far as the issue of truth is concerned, culminated in the work of Tarski.

\section{Husserl on the Empirical Cognition of Objective Truth}

In his Logical Investigations of 1900/01 Husserl moves beyond Twardowski by distinguishing, in addition to the content and the object of the judging act, also its quality. ${ }^{28}$ Quality and content are two independent dimensions of variation in the space of mental acts. The quality of the act is that moment of the act which determines whether it is an act of judgment, of assumption, of doubt, and so on, and it may vary even though the associated content remains fixed. Thus I can believe that John is running, doubt that John is running, wonder whether John is running, and so on. The content, on the other

\footnotetext{
${ }^{27}$ Meinong 1965, pp. 143f.

${ }^{28}$ Husserl 1894, 1900/1901, VI, §§ 28, 33, 39.
} 
hand, is that moment of the act which determines what the relevant object shall be, and it also determines as what the object shall be grasped in the act in question. ${ }^{29}$

Husserl's theory has its counterpart in the writings of Frege, where the threefold theory of act-quality, content and object appears in linguistic guise as the threefold distinction between expression, sense and reference. Husserl's 'quality' corresponds to Frege's 'force'. ${ }^{30}$ Frege, notoriously, had difficulties integrating the psychological dimension of judgment into his language-based approach. ${ }^{31}$ Husserl goes beyond Frege, however, in that he succeeded in constructing an integrating framework in which both the psychology of the judging act and the theory of linguistic meaning and of the structure of meanings play a role. This explains the powerful influence of the Logical Investigations, which was not confined to the astonishingly rapid and well-documented effect of its first volume, the 'Prolegomena to Pure Logic', which did much to dislodge from their position of dominance the psychologistic theories which had hitherto prevailed in logical circles. ${ }^{32}$

According to Husserl, when we use a linguistic expression, the expression has meaning because it is given meaning through an act of a special kind. Such meaninggiving acts are, he holds, always of the same form. They are acts in which a corresponding object is given intentionally to the language-using subject. 'To use an expression significantly, and to refer expressively to an object', Husserl tells us, 'are one and the same. ${ }^{33}$ An act of meaning is 'the determinate manner in which we refer to our object of the moment'. ${ }^{34}$

The object-directed and the meaning-bestowing components of the act are fused together into a single whole. This means that they can be distinguished only abstractly: they are not experienced by the subject as two separate parts in the act. Thus, the bestowal of meaning does not, for example, consist in some deliberate cognitive association of a use of language with some ideal meaning of a Platonistic sort. Husserl

\footnotetext{
${ }^{29}$ Husserl 1900/1901, V, § 20.

${ }^{30}$ Frege 1879, §§ 2-4. See also Bell 1979, pp. 83-106.

${ }^{31}$ This is shown inadvertently by Dummett 1973/1981, p. 681. See also Dummett 1993, esp. ch. 10, "Grasping a Thought" and Chapter 1, "Husserl on Perception". Compare Smith 1989.

32 See Kusch 1995, whose treatment however focuses on the sociopolitical dimensions of the problem in question.

${ }^{33}$ Husserl 1900/01 (1970, p. 293).

${ }^{34}$ Husserl 1900/01 (1970, p. 289). On the wider implications of Husserl's cognitive theory of meaning see Schuhmann and Smith 1987 and Smith 1990.
} 
therefore - in contrast to Bolzano and Frege - does not see meanings as ideal or abstract objects hanging in the void in a way that would leave them set apart from concrete acts of language use, and in need of being glued together therewith (Dummett's "linkage problem" (1988)). But like Bolzano and Frege, Husserl still sees the need for some ideal or abstract component as a basis for his account of the necessity of logical laws. He also needs to find some way to account for the fact that one and the same meaning can be used on more than one occasion. How can the same meaning be realized by different subjects at different places and times? (Recall that we had left this problem dangling in our treatment of Brentano.) Husserl answers these questions by developing an account of meanings as the kinds or species (types) of the associated meaning acts (tokens). The theory according to which an act gets its meaning from its direction towards an object implies that meaning acts can be divided into different classes on ontological grounds, which is to say: according to the nature of their objects. The most important such division for our purposes is that between acts associated with the uses of names, which are prototypically acts of presentation, and acts associated with the uses of sentences, which are prototypically acts of judgment. The former are directed towards objects in the narrow sense, the latter towards states of affairs. ${ }^{35}$ (Husserl adopts Stumpf's term 'Sachverhalt' to refer to the state of affairs as truthmaker of a judging act. A Sachverhalt is, for example, that John is happy or that this rose is red.)

A meaning act involving the use of a name may occur either in isolation or undergoing in the process a certain sort of transformation - in the context of a meaning act involving the use of a sentence. ${ }^{36}$ The meanings of names, which Husserl calls concepts, are species of acts of presentation; the meanings of sentences, which Husserl calls propositions, are species of acts of judgment. To say that my use of 'red' means the same as your use of 'red' is to say that our corresponding acts exhibit certain salient similarities in virtue of which they (the acts) can be seen, from the perspective of someone who shares an understanding of the English language, as being of the same sort. More precisely, we should say that, just as it is only a certain part or moment of the red object (roughly: its surface) that instantiates the species red, so it is only a certain part or

\footnotetext{
${ }^{35}$ See Mulligan 1990.

${ }^{36}$ Husserl 1900/01 (1970, p. 676).
} 
moment of the mental act which instantiates any given meaning-species, namely that part or moment which is responsible for the act's intentionality, for its being directed to an object in just this way. ${ }^{37}$ The meaning is this moment of directedness - the objectifying act referred to above - considered in specie. The identity of meaning from act to act and from subject to subject is then the identity of the species, a notion that is to be understood in turn against the background of that type of immanent realist theory of species and instances that is set forth by Aristotle. ('Immanent' here means: the universal exists in, it is a special sort of part of, the particulars that instantiate it. ${ }^{38}$ )

It is important to stress that meanings so conceived are not themselves the objects of normal acts of language use. We do not, in the normal course of mental experience, mean the meaning of an expression by having this meaning as the target (object) of any associated intentional act. Husserl, just as much as Brentano, is far removed from any view of judgment and belief in terms of 'propositional attitudes'. Rather, in using the expression as a component of an act of being directed toward an appropriate object or state of affairs, we bring it about without further effort on our part that the meaning is instantiated.

Meanings can become objects or targets of special types of reflective act; it is acts of this sort which make up the science of logic. Logic arises when we treat those species which are meanings as special sorts of proxy objects (as 'ideal singulars'), and investigate the properties of these objects in much the same way that the mathematician investigates the properties of numbers or geometrical figures. ${ }^{39}$ Just as geometrical figures are what result when concrete shapes are treated in specie, disembarrassed of all contingent association with particular material and context, so the subject-matter of logic is made up of what results when concrete episodes of language use are treated in specie, which is to say: in abstraction from the peculiarities of their context of use. And just as terms like 'line', 'triangle', and 'hemisphere' are equivocal, signifying both classes of factually existing instantiations and ideal singulars in the geometrical sphere, so terms like 'concept', 'proposition', 'inference', and 'proof' are equivocal: they signify both classes of mental acts belonging to the subject-matter of psychology, and ideal singulars in the

\footnotetext{
${ }^{37}$ Husserl 1900/01 (1970, pp. 130, 337). See also Willard 1984, p. 183f. and the references there given.

${ }^{38}$ See Aristotle, Physics, IV 2, and compare Smith 1992a.

${ }^{39}$ See Smith 1989a.
} 
sphere of meanings. Brentano's phobia of abstract entities prevented him from developing any ideas along these lines, and thus his writings on logic never reach the sort of sophistication that we find in the work of Frege and Husserl and Bolzano.

Husserl made advances over Brentano also through his recognition of a syntactic dimension in the realm of judgment. That is, Husserl saw that acts of judgment are distinguished from acts of presentation not only by the presence of a moment of assertion or belief but also by a special propositional form. A judgment must have a certain special sort of complexity, a complexity that is not merely a matter of combination. This complexity expresses itself linguistically in the special form of the sentence, and is reflected ontologically in the special form of the state of affairs. In the fourth of his Logical Investigations Husserl sketches the idea of a science of 'logical grammar'. This is a formal theory of the categories of linguistic units (more specifically: of their counterparts in the sphere of meanings) and of the categorical laws governing the ways in which such units can be put together to form larger complex wholes. The theory is based on the idea that there is a parallelism of structure between immanent contents on the level of our empirically executed acts, on the one hand, and meaning-universals on the level of logic, on the other. ${ }^{40}$ Husserl is thereby able to account in a very natural way for the fact that the laws of logic apply to actual thinkings, speakings, and inferrings. At the same time his conception of meanings as Aristotelian species provides him with at least the germ of a way of doing justice to the necessity that accrues to such laws.

Recall the problem that arose for Bolzano's theory of sentences in themselves. How can we be acquainted with entities outside space and time? Husserl provides a solution to this problem that falls between the extremes of psychologism (of the sort propounded by the more orthodox Brentanians) and Platonism (of the sort propounded by Bolzano himself and by Frege). It was not least because it tended towards the psychological extreme by abandoning the 'Platonism' of ideal contents that the Brentanian treatment of logic and its laws was less than successful. But in overreacting to the perceived dangers of psychologism, Frege and his successors in the analytic tradition

\footnotetext{
${ }^{40}$ This part of Husserl's work, despite its Aristotelian connotations, exerted an influence also on logical developments in Poland, where it led to the formulation by Lesniewski and others of what is now called categorical grammar. Ajdukiewicz's essay of 1935 on "Syntactic Connexion" is the first published formalization of the ideas on meaning-categories set out by Husserl in his fourth Logical Investigation.
} 
moved too far away from questions of psychology. They were thus unable to do justice to the relations between logic and those empirical events of thinking and reasoning in which logical truths become instantiated.

\section{Marty on the Objects of Empirical Judging Acts.}

Marty's Investigations on the Foundations of General Grammar and Philosophy of Language of 1908 represents one exceptional attempt by a more orthodox follower of Brentano to explain in a systematic way the relations between cognitive activities, on the one hand, and our uses of language, on the other, taking account also of their ontological correlates. The work was designed to serve as a presentation of Brentano's ideas as applied to the linguistic domain. It was influential through its impact on such thinkers as Stanislaw Lesniewski, Karl Bühler, and Roman Jakobson, as well as on Brentano's own views on language.

Following Brentano, Marty divides psychological phenomena into the three basic classes of presentations, judgments, and phenomena of love and hate. He then argues that there are correspondingly three basic classes of linguistic forms reflecting the corresponding basic classes of psychological phenomena. ${ }^{41}$ The relations between sign and experience he explains via an account of what he calls 'the communicative functions of language', which he sees as being realized - in a way that recalls Frege's famous context principle ${ }^{42}$ - primarily through sentential utterances. A sentential utterance, according to Marty, has three functions:

1) to express the occurrence of a judgment on the part of the speaker,

2) to evoke a corresponding judgment on the part of the receiver,

3 ) to refer intentionally, which means: to be of or about what Marty calls a 'judgment-content'.

Marty's judgment-contents are on the one hand analogous to the truths in themselves of Bolzano's philosophy, in that they serve as the measure or standard to which an actual

\footnotetext{
${ }^{41}$ Marty 1908, p. 226.

${ }^{42}$ Frege 1884 , Introduction and $\S \S 60,62,106$.
} 
judging, if it is to be true, must conform. ${ }^{43}$ On the other hand, however, where Bolzano's propositions in themselves serve as the bearers of truth, Marty's judgment-contents are truthmakers, which means that they do not themselves have truth and falsehood as properties, but are rather object-entities to which judgment, if true, will correspond. Marty's judgment-contents differ from Bolzanian truths in themselves also in that they are not ideal or extra-temporal. Rather, a judgment-content, like everything else for Marty, exists in time. It is however not real, for a judgment-content does not have or suffer effects; it is not part of the causal realm. Marty holds further that the judgmentcontent is dependent for its existence on the relevant act of judgment, from which we can infer that, like the latter, it enjoys a merely fleeting existence. The judgment-content cannot exist unless the judgment exists, but the existence of the judgment (if true) brings with it automatically the existence of the judgment-content. Judgment-contents are in this respect analogous to the Sachverhalte of Stumpf.

From Marty's point of view, a judgment is true when there obtains an adaequatio cogitantis et cogitati in the sense of an actual correlation. Such a correspondence can obtain, he holds, only if the specific relata of this relation themselves exist simultaneously. The relation of adequation then holds between the meaning that is communicated in a particular judging act and a certain corresponding judgment-content, which we can think of as a fact or state of affairs. If I say, 'John is kissing Mary' what I want to communicate is a certain meaning. My communication may succeed even though my judgment is false. Even if John, is not, in fact, kissing Mary, we are still able to understand what is meant by the utterance. However, only true judgments have contents in the sense of truthmaking states of affairs. False judgments, on Marty's theory, do not correspond to any special non-obtaining state of affairs of the sort that were admitted by Meinong.

But if truthmakers exist only fleetingly, does this not come close to making truth itself dependent on our acts? Can we really conceive Marty's view as amounting to a defense of the classical correspondence theory of truth if he sees the truthmaker as ontologically dependent upon the judging act that brings it into being?

\footnotetext{
${ }^{43}$ For more details of Marty's ontology of the truth-relation see Smith 1994, Chapter 4. Marty in his early writings embraces the position of Brentano's Logic lectures of the 1880s (see Chrudzimski 2001 and 2001a). We discuss in the text Marty's later views.
} 
Marty's answer to this question is to hold that the state of affairs, although dependent for its existence upon the act of judging, is yet determined in its nature independently of this act. Its nature is determined from the side of reality by the relevant object of presentation. Both expressed meaning and judgment-content are mediators between judgments and the objects presented in their underlying presentations. Truth itself is the bridge which spans the divide between judging act and expressed meaning on the one hand, and judgment-content and underlying object of presentation on the other.

The relation of truth then exists only in those instances of correspondence that arise through judging acts occurring at given points in time. The necessary and sufficient condition for the existence of instances of the relation of truth is thus the co-existence of a process of judging and a corresponding judgment-content or state of affairs. A world without judging acts is, for Marty, a world without truth.

Marty insists that every truth, which is to say every obtaining correspondence between truthbearers and truthmakers, must be capable of being experienced by a cognitive subject. We should be able to grasp the truth of a judgment by grasping its adequacy to the corresponding state of affairs. When this correlation is grasped, then truth itself is experienced. The correspondence between the act of judging and the state of affairs causes the experience that is required in order for us to be in a position to call a judgment 'true'. Such an experience of adequation is possible because both terms of the experienced relation of correspondence are dependent upon our judging acts. Both the expressed meaning and the judgment-content are in some sense subject-dependent: they exist only at the time when a judging act occurs.

\section{From Husserl to Munich Phenomenology}

Husserl's Logical Investigations initiates a new discipline of formal ontology, which studies scientific object-domains in a way analogous to the way in which formal logic studies sciences as systems of propositions. The basic concepts of formal ontology are concepts such as: object, state of affairs, part, whole, and dependence. It was especially among those early and enthusiastic readers of Husserl's Logical Investigations who congregated in Munich around Johannes Daubert, Alexander Pfänder and Adolf Reinach that the implications of these aspects of Husserl's thinking were intensively pursued. 
Daubert himself developed a theory of states of affairs as entities of a naturalistic ontology: the state of affairs is a truthmaking segment of reality that is 'thrown into relief' through an act of judgment. ${ }^{44}$ The Daubertian state of affairs is thus dependent upon consciousness for its demarcation, but it is yet an objective part of nature in the sense that what gets demarcated exists independently of the demarcating act. States of affairs are like Poland. The latter exists only because there are people, their beliefs and actions. But the underlying territory - das unterliegende sachliche Tatbestandsmaterial, as Reinach might call it - exists whether or not people come along to claim it. Only in those cases where we are judging about mental entities is the relevant truthmaking state of affairs an entity immanent to the mind.

Unfortunately, however, Daubert published not a single line during his lifetime, and his ideas remained inaccessible until his peculiar shorthand was deciphered by Karl Schuhmann, who conceived the project of transcribing Daubert's work. More important is the work of Adolf Reinach, who gave Husserl's ideas on logic, truth and meaning an especially pregnant form in the ontology of states of affairs and judgments developed in his "On the Theory of the Negative Judgment" of 1911. It is in this work that the two concepts of proposition and state of affairs are finally clearly distinguished. Propositions are the meanings of judgments; states of affairs are objectual truthmakers - and the latter are genuinely independent of the judgments directed towards them. For Reinach, states of affairs exist in a Platonic realm; they are eternal and unchanging. The realm of states of affairs comprehends the objectual correlates of all possible judgments, whether positive or negative, necessary or contingent, simple or complex, true or false. A state of affairs gains its foothold in reality through the objects it involves; it is of or about these objects. Reinach is thus in a position to conceive states of affairs as the locus of existence of the past and of the future, and so as truthmakers for our present judgings about past and future objects and events. He is thus able also to guarantee the timelessness of truth while at the same time avoiding that sort of running together of truthbearer and truthmaker that is characteristic of the work of Bolzano.

Reinach's ontology of states of affairs constitutes one further sign of the fact that, by 1911, the subject-matter of logic had been expelled once and for all from the realm of

\footnotetext{
${ }^{44}$ See Schuhmann and Smith 1987, Schuhmann 1998, Smith 1999.
} 
the mental. The logicians responsible for this expulsion were each called upon to provide some alternative account of what this subject-matter ought to be. Frege and Bolzano appealed to ideal meanings. But as already noted, the appeal to ideal meanings brings the problem of how such meanings can be 'grasped' by mortal thinking subjects such as ourselves, and also the problem of how such meanings are related to contingent objects in reality. Reinach avoids this problem by conceiving the subject-matter of logic as consisting neither in ideal meanings nor in the expressions of meanings in language, but rather in the objectual correlates of judging acts. Logic is a science of states of affairs. A view along these lines can provide an alternative to psychologism only if it can somehow guarantee the objectivity and necessity of logical laws. This Reinach achieves precisely by viewing states of affairs in a Platonistic way: he granted them a special status of the sort that was granted to propositions by Bolzano and to thoughts by Frege.

Reinach's states of affairs are transcendent to the mind; they are entirely independent of all mental activities. Since they stand apart from the spatio-temporal domain, they play no role in causal relations. In these respects Reinachian states of affairs resemble sets as standardly conceived in mathematics. Like sets, states of affairs are constituted by ordinary objects, but in a way that somehow suspends the latter's mutability. According to Reinach, the realm of states of affairs is complete, in the sense that there is a state of affairs precisely coordinated with every possible judgment. His principal reason for accepting a completeness of this sort is that it permits us to uphold the correspondence theory of truth in its full generality. Negative judgments in particular are correlated with special negative states of affairs in just the same way that positive judgments are correlated with their positive counterparts. Positive and negative states of affairs are then entities of the same Platonic sort. But where it is possible to conceive a positive state of affairs like this dog is black as some sort of real complex (a combination of the dog and its blackness), no such view is possible for negative states of affairs like this dog is not yellow or unicorns do not exist. The latter cannot be counted as real complexes in any sense, and thus it is hard to see how we could find a place for them as denizens of empirical reality.

In putting positive and negative states of affairs together in a single homogeneous realm, Reinach can provide a single homogeneous subject-matter for logic. This is at a 
price, however, for it means that he has a correspondingly weak account of the relation between a state of affairs and the objects it 'involves'. Some states of affairs - for example that John is kissing Mary - do indeed involve ordinary objects of experience and it is in relation to these cases that Reinach formulates his account of how we grasp states of affairs in cognition by showing how acts of judgment and states of belief are built up on the basis of acts of perception in which the corresponding objects are presented to the subject. No such account can be given, however, in relation to states of affairs of many other types, for example in relation to negative states of affairs such as 'Pegasus does not exist'. Negative states of affairs are however indispensable to Reinach's project of conceiving logic as a science of states of affairs. ${ }^{45}$

One of Reinach's most original contributions is his theory of the sorts of acts in which states of affairs are grasped, and of the various attitudes that have states of affairs as their objects. His account of how such acts and attitudes relate to each other and to the acts and attitudes that have judgments and propositions as their objects provides the basis for a theory of different types of negative judgments of a sophistication that has rarely been matched in subsequent literature. ${ }^{46}$ His most important contribution, however, consists in his elaboration of the first systematic account of what would later be called the theory of 'speech acts'. Husserl's theory of linguistic meaning was based, as we saw, on his theory of the object-directedness of acts. According to this theory, all expressions are associated either with nominal acts or with acts of judgment. Husserl's disciples in Munich argued against this judgment-based theory of linguistic meaning in a series of steps brought to culmination in the theory of speech acts put forward by Reinach in his monograph on The A Priori Foundations of the Civil Law in 1913. It was above all Daubert who made the first crucial steps away from Husserl's theory of linguistic meaning in terms of object-directed acts in his theory of questions, a theory based upon the insight that we can be related to reality in our use of language not just in the modes of

\footnotetext{
${ }^{45}$ Aristotelians, we might note, would have a similar problem in defending Aristotle's account of negative judgments as a matter of 'separation' in those cases where there is nothing in reality that is available to be separated out. Aristotle himself could solve this problem, at least in part, through his doctrine of the fixity of speeches. For the latter guarantees that general terms have reference in every case through their instantiations in suitable particulars.

${ }^{46}$ Reinach 1911. See also Smith 1978, 1987 and 1989a.
} 
presentation and judgment but also in a sui generis act of questioning. ${ }^{47}$ Reinach then generalized Daubert's critique of Husserl's theory of meaning to apply to the entire range of speech acts, including speech acts of the legal sort.

\section{Twardowski: Against the Relativity of Truth}

It was especially in Poland that work on the theory of judgment and truth in the BolzanoBrentano tradition continued to flourish after the turn of the last century as a result of the powerful influence of Twardowski, whose students included almost all the important figures in Polish logic of the early decades of the 1900s.

For Brentano, and later for Marty, truth is something episodic. A judgment is true only on the occasion of its actual utterance - for only then does it exist. They thus conceive truth as being relative to the context in which acts of judging occur or to the occasion of a use of language. This subjective element in the theory of truth was connected with the Brentanian conception of acts of judgment as the bearers of truth (as also with Brentano's presentistic ontology).

Twardowski, in contrast, inspired in this connection by Bolzano, argues in favor of a conception of truth as something objective. ${ }^{48}$ Yet he still holds on to the thesis that it is judgments which are the bearers of truth. Thus he needs to show how we can hold on to the objectivity of truth without the assumption of any ideal entity modeled on Bolzano's propositions in themselves. One form of the doctrine according to which truth is subjective appeals to the fact that the same sort of judgment, for example 'It is raining' or 'I am hungry', can be true as uttered by one subject and false as uttered by another. As Twardowski points out, however, this argument rests on a confusion of judgment on the one hand with its statement or expression on the other. In order for speech successfully to play its communicative role we must restrict our choice of words to those which are indispensable in a given context, which means: to those which are necessary in order to yield a sufficient understanding of our judgment on the part of our audience. We thus speak elliptically. We say 'It is raining' when what we mean is 'It is raining at 8:59 AM Central European Time on the south side of the Rhine near Koblenz on the 5th of October

\footnotetext{
${ }^{47}$ See Schuhmann and Smith 1987 and Smith 1990.

48 Twardowski 1902.
} 
in the year 2000 A.D.' This elliptical manner of speech is a central feature of our everyday language. Speech, we might say, is a mere surface phenomenon: judgment, on the other hand, goes deep, and bears no traces of the ellipsis that is generated by contextual and subjective factors. The judgment itself is filled out in every case in such a way as to include the precise representation of time, place, and all other conditions relevant to its truth. The bearer of truth is then, on Twardowski's view, still the judgment, and the judgment is still episodic. Now, however, it is seen as being represented only partially in the sentence that expresses it. And the judgment as thus understood clearly does not change its truth-value on different occasions of use.

A parallel argument can be found in different forms in the work of Frege and Russell. It can also be found in Wittgenstein's Tractatus, for example in the remark to the effect that language 'disguises thought. So much so, that from the outward form of the clothing it is impossible to infer the form of the thought beneath it. ${ }^{49}$

In Twardowski's formulation the argument is part of an attempt to come to an understanding of the mental acts involved in judging. Twardowski is not attracted by the more ambitious task of building an ideal or artificial language within which judgments would receive their canonical expression. His efforts are directed not to the construction of abstract models, but rather to the understanding of the very processes that are involved in actual judgings. Twardowski's insistence on the notion of objective truth did, however, have implications for subsequent developments in logic, since it led his students - among them Lesniewski and Kotarbinski - in the direction a truth-functional conception of logic in the modern sense. ${ }^{50}$

\section{Twardowski's Theory of Acts and Products}

One step along this road is the theory of acts and products set forth by Twardowski in his paper 'On Actions and Products' of 1912. The distinction between acts and products goes back once more to Stumpf, with his distinction between functions and formations

\footnotetext{
${ }^{49}$ Wittgenstein 1921, 4.002.

${ }^{50}$ On the influence of Twardowski's views in this respect see Wolenski 1989, 1998 and Rojszczak 1998, 1999.
} 
(Stumpf 1907) ${ }^{51}$ Functions include mental processes such as judging or evaluating. What comes into being as a result of a function is called a 'formation' by Stumpf and a 'product' by Twardowski. As the act of speaking gives rise to speech, so the act of thinking gives rise to thought.

Twardowski divided acts and their products into the three classes of mental, physical and psychophysical. Products can be divided further into transient and enduring. Your mental image of a house is a transient mental product. You can, however, transform it into an enduring physical product, for example by drawing a picture or plan or even by building a house in conformity with your image. It is the possibility of transforming transient mental products into psychophysical products such as utterances, and into enduring physical products such as printed books, that enables us to go beyond the mental sphere and as it were objectify and institutionalize the ephemeral processes of the mind.

Twardowski is thus in a sense offering us a theory of how intentionality can be conveyed and disseminated via causal processes. Above all his theory of meaning is built up on the basis of his theory of acts and products. Psychophysical products are able to manifest what takes place inside our minds in that our mental products are able to cause the coming into being of associated psychophysical products which are accessible in sensory experience. If the psychophysical product that manifests to us a given mental product causes similar mental products in different subjects, for example when we tell a story, then it expresses this mental product. Where a given psychophysical product expresses a mental product, we call the first a sign of the second, and the expressed product we call its meaning.

The term 'judgment' is ambiguous; it can signify either the judgment in the psychological sense, the function or activity of judging, or the judgment in the logical sense, its product. The latter exists only when someone judges, but it can become fixed in an enduring physical product - for example it can be written down - and to this extent live on. There is thus a strong relation between thinking on the one side and language on

\footnotetext{
51 Twardowski counts among his predecessors in making this distinction also Bolzano 1837, Bergmann 1879 and Witasek 1908.
} 
the other. Clarity in judging thus has its counterpart in clear sentences, and clarity in philosophical writing, in particular, reflects clarity in thinking. ${ }^{52}$

The written or spoken sentence expresses the judgment by causing the same judgment in other persons. Judgments fixed in sentences then appear to us not only as enduring products but also as entities independent of the acts which served to give rise to them initially. The sentence causes just as many different thoughts as there are different persons who read or hear it, but in talking of the meaning of the sentence we abstract from all these differences. Twardowski's theory of meaning thus bears comparison with the species theory of meaning developed by Husserl in the Logical Investigations. For Twardowski, however, meaning is not a species of acts but rather a species of products of acts, or better, since Twardowski himself was skeptical as regards the terminology of species, it is something invariant which many such products share in common.

Twardowski's theory also has implications for our understanding of the nature of the formulae of symbolic logic. Artificial logical products do not express authentic judgments at all, Twardowski holds. Rather they express mere presentations of judgments that are themselves entirely independent of any associated psychological moment of conviction. This explains, according to Twardowski, why logical formulae are not assertible. Thus in his account of the objects of logic Twardowski does not appeal to anything like Bolzano's idea of propostions in themselves. Meinong had at the same point in the argument seen fit to amend the Brentanian taxonomy of mental phenomena by introducing a new sort of psychological phenomenon, which he called assumption. ${ }^{53}$ We do not judge the formulae of logic, Meinong argues; rather we assume them. Twardowski, in contrast, embraces a view according to which we are directed towards the objects of logic via acts of presentation - namely acts of presenting judgments which are themselves expressed by certain special sorts of symbols. The latter are then to be conceived as mere instrumental aids, comparable to the use of digits in arithmetic.

\section{Jan Lukasiewicz on Psychologism and Truth-Bearers}

\footnotetext{
${ }^{52}$ See Twardowski 1919-20

${ }^{53}$ See Meinong 1902.
} 
It was in Lukasiewicz's "Logic and Psychology" of 1907 that the issue of psychologism was first discussed in Poland, and it was in fact this essay that motivated Lukasiewicz's teacher Twardowski to develop his own theory of acts and products. Lukasiewicz, referring directly to Husserl, argues that the task of logic is to find the objective laws governing the connections between the truth and falsity of judgments. The confusion between psychology and logic comes about as a result of an ambiguity in the basic concepts of the two disciplines. On the one hand is the judging act considered psychologically - i.e. independently of any expression in a sequence of words - for which Lukasiewicz also uses the term 'belief'. On the other hand however is the judgment in the logical sense, which is for Lukasiewicz the objective correlate of a mental act of judging. Thus Lukasiewicz proposes to solve the problem of psychologism in a manner which anticipates later analytic philosophy as epitomized, for example, by Dummett (1988) - namely by taking a linguistic path out of the subjective realm of the psychological, by appealing to the intersubjectivity of language as the locus of the objectivity of logical laws.

Lukasiewicz compares judgments in the logical sense with Meinong's Objectives, entities which themselves bear many similarities to Sachverhalte in the tradition of Stumpf and especially of Husserl and Reinach. ${ }^{54}$ Lukasiewicz himself studied with Meinong in Graz from 1908 to 1909, though his concept of judgment in the logical sense arose independently of Meinong's concept of objective. According to Lukasiewicz there are no judgments in the logical sense without language. Only if a judgment exists as (or is expressed as) a sequence of words (either spoken or written) does it exist as a judgment in the logical sense. ${ }^{55}$ Thus, the judgment as considered by logic is neither a mental act of judging nor an ideal meaning. Rather it is a sequence of words. Each judgment in the logical sense is directed to objects in the world via concordance or non-concordance, or in other words the corresponding sequence of words can be predicated as true or false. Judgments in the psychological sense can be correct or incorrect. But only in a secondary sense can they be true or false. ${ }^{56}$

\footnotetext{
${ }^{54}$ See Lukasiewicz 1907, p. 490.

${ }^{55}$ Lukasiewicz 1910 (1987, p. 12).

${ }^{56}$ Lukasiewicz 1910 (1987, p.12).
} 


\section{Lesniewski and Kotarbinski on the Objectivity of Truth}

Lukawiesicz's essay on the principle of contradiction in Aristotle, published in 1910, stimulated a series of discussions in Poland focusing on the issue of the objectivity of truth in connection with the issue of freedom and determinism. It was Kotarbinski, another pupil of Twardowski, who had first pointed to an apparent inconsistency between Bolzano-style doctrines of objective truth and the idea of freedom (Kotarbinski 1913).

Kotarbinski and Lesniewski discussed this problem within the framework outlined earlier by the Brentanians and focusing on an issue that had arisen in connection with Marty's theory of truth: the problem of the simultaneous existence of episodic judgments and their objectual correlates. How are we to understand the objectual correlates of judgments about the past and the future? What makes it true (now) that 'John will kiss Mary at 4 o'clock tomorrow'? In addressing this problem Lesniewski and Kotarbinski used an argument that focused on the principles of classical logic rather than on the psychological description of our mental life.

If truth is independent of time, Kotarbinski argues, then this implies a kind of determinism. ${ }^{57}$ How is it possible that a judgment that I make in the present about an object in the future should be true already now? According to the classical theory of truth, a judgment is true if and only if it corresponds to some correlated reality in the world. A judgment about the future cannot (it seems) be true now. But such a judgment cannot be false, either. For otherwise, because of the eternity of truth, it would be false forever. Consider the judgment: my hair will be short tomorrow. It seems that I can decide, now, whether or not to cut it. I have a role in determining whether the judgment is (or will be) true or false. I am able to create the object to which the judgment would need to correspond if it wanted to be true. Such considerations, Kotarbinski argues, are inconsistent with the thesis according to which judgments are true forever (assuming that they begin to be true at a certain point in time).

In his response to Kotarbinski, Lesniewski - another student of Twardowski defends the absolute view of truth defended earlier by Bolzano and Twardowski. ${ }^{58}$ Where for Kotarbinski it is the objects of judgment which are seen as past, present or future, for

\footnotetext{
${ }^{57}$ Kotarbinski 1913.

${ }^{58}$ Lesniewski 1913.
} 
Lesniewski these objects are seen as being timeless. What is past, present and future is rather the existence of the object. Lesniewski can by this means defend the view that an affirmative judgment which refers to an object can be true even when this object does not exist simultaneously with the judgment. I can make a true judgment tomorrow that I wrote these lines today. Similarly, I can make a judgment today about lines I will write tomorrow; my judgment is then already about a certain object, albeit one which will come into existence only tomorrow.

Lesniewski sees the relation between a judgment and its truth-value as something absolute. This means that the relation obtains independently of time, place and context of judgment, even though judgments themselves are only episodic. From this it follows that truth can never claim to be eternal in a strong sense. As for Marty, so also for Lesniewski, it is a relation which obtains only episodically. This is one of the earliest expressions of that nominalism which would play so powerful a role in Lesniewski's later thinking.

We have seen traces of the nominalism dominant in Poland already in Twardowski's episodic view of judgment-correlates (and in similar views on the part of Brentano himself). The specifically Polish variant of nominalism arose out of a discussion about general objects which began with Lesniewski's paper of 1913 on the logical law of the excluded middle. As Lesniewski later wrote, he believed at the time of this paper,

that there are in existence in this world so called features and so called relations, as two special kinds of objects, and I felt no scruples about using the expressions 'feature' and 'relations'. It is a long time since I believed in the existence of objects which are features, or in the existence of objects which are relations and now nothing induces me to believe in the existence of such objects. (Lesniewski $1927(1992, \mathrm{p} .198))$

It is a remarkable fact that the very same problem of the objects of judgment led to such completely different types of solutions: on the one hand to the rich ontologies of Meinong and his followers in Austria; on the other hand (and certainly in combination with other motives) to the nominalistic positions accepted by philosophers such as Lesniewski and Kotarbinski in Poland. 
Lesniewski's nominalism makes itself felt also in his views on language and judgment. Each linguistic expression is, he holds, composed of only a finite number of concrete parts. Two distinct sequences of such concrete parts are two distinct expressions. According to this view,

if we call an object 'eternal' on the ground that it never ceases to be, then no

judgment need be eternal in this sense: it ceases to last at the moment when it is uttered for the last time. (Lesniewski 1913 (1992, p. 96) $)^{59}$

Lesniewski still affirms the absoluteness of truth, however, in the sense that, for him, if a judgment is true at any time, then it is true at every time at which it is brought to expression, written down, experienced, or lived through. ${ }^{60}$

\section{Maria Ossowska on the Functions of Sentential Inscriptions}

In order to move the bearers of objective truth from the realm of judging acts to the realm of sentences it was necessary to become clear about the different functions of language, and above all about the differences between the function of language to express our thoughts and the other semantical functions such as referring or presenting. Among philosophers in Poland it was above all Maria Ossowska who made progress in this respect, and here, too, the influence of Husserl's Logical Investigations made itself felt.

Ossowska attempts first of all to categorize the ways in which the words 'expression' and 'expressing' are used. She takes sentences as the primary linguistic entity, where for Brentanians it had been the noun or noun phrase - the expressions of presentations. For Brentano, we remember, a judgment is nothing more than an attitude of affirmation or rejection directed towards the object of a presentation. What is expressed in a sentence is a thought. And the latter, according to Ossowska, who draws here on Meinong's treatment of the psychology of thinking, is an experience which is either a belief or an assumption (the latter conceived, in Twardowski's spirit, as a presentation of a judgment). ${ }^{61}$ Ossowska points out that

\footnotetext{
${ }^{59}$ See also Wolenski 1989 and Simons 1993.

${ }^{60}$ Lesniewski 1913 (1992, p. 95).

${ }^{61}$ Meinong counts under thinking only two classes of mental phenomena: acts of judgment and assumptions.
} 
the property of presenting is the same property which Russell and others call the transparency of the linguistic sign, and it consists in this: that an uttered or a written ... linguistic phrase makes us switch over our thought to something other; with its mediating help we think about something different. (Ossowska 1931, p. 204)

We can express a thought by means of a linguistic sign. Thoughts are equivalent if our linguistic habits make us express them by means of the same linguistic expression. There then obtains a special counterpart relation between the act of thought and the utterance of the sentence which expresses it. ${ }^{62}$

Ossowska holds that the sentence then pictures the underlying thought. This picturing can be understood in different ways, for example as the structural similarity of the parts of the sentence with parts of the presented thought. The sentence can also have the property of suggesting (or evoking) the thought, an idea we met already in our discussion of Marty. The function of expression is in Ossowska's eyes a property of an utterance or an inscription.

Ossowska herself opted for a view of expression as the property possessed by a sentence when it manifests the presence of a thought which underlies it:

The sentence $\mathrm{S}$ expresses the thought $\mathrm{T}$ in the language $\mathrm{L}$ iff there is some person $\mathrm{X}, \mathrm{S}$ is uttered or written by $\mathrm{X}$, and the utterance or writing down of $\mathrm{S}$ by $\mathrm{X}$ occurs not earlier than the thought $\mathrm{T}$ on the part of $\mathrm{X}$, and $\mathrm{S}$ is of the same shape as the sentences which under normal situations are uttered or written in $\mathrm{L}$ when one wants to inform someone about T. (Ossowska 1928, p. 146)

Ossowska refers in this connection to the theory of indication or Anzeigen set forth by Husserl in the first Logical Investigation.

According to Ossowska we can make also an additional assumption: that the sentence $\mathrm{S}$ which manifests a thought should not refer directly to the thought of which it is the expression. The sentence 'I think that this rose is red' is an expression of a thought, not however of a thought about a rose but rather of a thought about a thought. If the

${ }^{62}$ Ossowska 1931, pp. 208-9, 235-239. 
sentence $\mathrm{S}$ expresses a thought $\mathrm{T}$, then it should not present to us the thought $\mathrm{T}{ }^{63}$ This extra condition is introduced in order to prevent us from confusing the two functions of expressing and presenting.

What is expressed by a sentence is, above all, what Husserl called an act of meaning-bestowal. Such an act, for Ossowska as for Husserl, is a necessary condition of the written sentence's having meaning. One can conceive the sentence either in its function of presenting or in its function of expressing. But one can conceive it in its function of presenting only if one assumes that the linguistic sign is intentional, i.e. if one assumes that the linguistic sign is an expression of a meaning-intention.

Kotarbinski defended a view according to which the function of expression in the sense just explained is primary in relation to a derivative presentational function:

To put it briefly, reference to the intention to communicate something, reference to the fact that a given phrase is adequately used to communicate something - for example, to predicate something by means of a given term - belongs to the essence of meaning. The fact that a given content of an image associates itself with a given word does not in the least prove that we want to communicate that content by means of that word (Kotarbinski 1929 (1966, p. 93)).

Is something meaningful because it expresses something or does it express something because it is meaningful? Ossowska answers this question by pointing out that it is indubitable that expressions are what come first in the course of learning language. However, from the point when once we have mastered a language, it seems to be that the opposite thesis holds, that is that it is meaning which enjoys primacy. ${ }^{64}$ And even if both of these functions appear closely bound together in our linguistic practice they should, Ossowska concludes, be clearly separated for the theoretical purposes of semantics.

\section{Stanislaw Ossowski on Semantical Products}

In 1926 Stanislaw Ossowski, Maria Ossowska's husband, returned to the function/formation (or act/product) distinction formulated earlier by Stumpf and Twardowski. For Ossowski, linguistic products are material objects; they are for example,

\footnotetext{
${ }^{63}$ Ossowska refers here to the problem of secondary expressions investigated by Meinong. See: Ossowska 1928 , p. 147, Ossowska 1931, pp. 224, 227-8, Meinong 1902, pp. 16-35.

${ }^{64}$ Ossowska 1931, pp. 233-234.
} 
graphical inscriptions correlated with one of the semantical functions of naming or referring. The correlation between a material object and its semantical function he then sees as depending on the intention of some cognitive subject. If an object is a semantical product, then there is a person who has a certain attitude - which Ossowski calls a 'semantical attitude' - to the object in question. The semantic attitude as it were passes through the object: a person has this attitude to a given object only if the person relates this object to some other object. ${ }^{65}$

Consider, for example, the case where John predicates of a rose that it is red. Here John does not have a semantical attitude to the rose. Rather his semantical attitude is directed towards the sequence of sounds which he utters when talking of the rose. John's attitude to this sequence of sounds is semantical only when John makes some connection between the sequence of sounds and the rose about which he speaks. But in order to be in a semantical attitude to that sequence of sounds, John need not make the connection directly between the sequence of sounds and the rose: he can also make the connection to the rose via some mental act or via some other object that is associated with this sequence of sounds. ${ }^{66}$

Every system of semantical concepts is, Ossowski claims, a conventional system. What this means is that everything in this domain must satisfy the condition that it is the product of somebody's intention. ${ }^{67}$ Ossowski's products - inscriptions, spoken sounds are similar to those of Twardowski. But there is one important difference. Twardowski demands of his psychophysical products that they are in every case made with a meaninggiving intention, or in Twardowski's own terms, that they are caused by mental episodes which are their meanings. Ossowski's semantical products, in contrast, require only that there be someone who has the appropriate semantical attitude to them independently of whether they were made with any associated meaning-giving intention. ${ }^{68}$ For example, we may interpret an accidentally drawn picture as if it had been made consciously to express some thought. One consequence of this view is that everything material can in principle be a semantical product.

\footnotetext{
${ }^{65}$ Cf. Ossowski 1926, p. 31.

${ }^{66}$ Kazimierz Ajdukiewicz derived one of his basic classes of meaning-directives, namely the empirical meaning-directives, from the explanation of associations advanced by Ossowski. See Ajdukiewicz 1934. ${ }^{67}$ Ossowski 1926, p. 54.

${ }^{68}$ In fact, Ossowski refers here to Husserl's notion of meaning as species: see Ossowski 1926, p. 32.
} 
Semantical products as described by Ossowski can be understood in two ways. First, they can be treated in relation to the objects to which they refer; that is, they can be treated in their semantical function. Second, they can be treated in relation to the mental acts of subjects who have the corresponding semantical attitudes. The function of expressing itself belongs, in Ossowski's view, to the province of psychology. Its task is to direct the thoughts of a subject to the objects to which the corresponding semantical products refer. For instance, John is traveling on the train from Berlin to Krakow and he sees the sign 'Stacja Rzepin'. If John understands Polish, and if he takes the semantical attitude to the sign he sees, then the expressing function of this sign (according to the rules of the Polish language, and according to the custom of hanging painted signs of this sort on railway station buildings) will lead John to think about the railway station on which the sign is fixed. This is because the referent of this sign is, precisely, the railway station in the town named 'Rzepin'. 69

Twardowski, as we saw, advocated a causal theory of meaning in the sense that, in the terminology of acts and products, each linguistic product causally inherits an intentional relation to a special sort of object, namely to the intentional object of the cognitive acts of which it is a product. Your sentence about John causally inherits a relation to John because the underlying act of judgment is intentionally directed to John. Twardowski treats the latter as causally 'infected' by the mental activity of the subject. Products are for Twardowski causal products. Ossowski, in contrast, breaks with such a position. He stresses not the aetiology of given semantic products but rather the subject's psychological attitude to the bearers of such properties. We can make almost anything we like meaningful by embracing appropriate semantical attitudes towards it, and thus by ascribing to it corresponding semantic properties.

You just read the paragraphs above. Your semantical attitude to the lines you read leads your thoughts, in Ossowski's view, to the notion of language. But what is language? According to Ossowski it is a system of conventional semantical products which, by means of conventional rules like those of grammar, create new complexes of semantical products with new functions. ${ }^{70}$ The functions of complex products are new in the sense

\footnotetext{
${ }^{69}$ Ossowski 1926, pp. 31, 56.

${ }^{70}$ Ossowski 1926, p. 35.
} 
that their function is not included in the basic conventional rules which are defined for simple semantical products. A complex product such as 'The rose is red', for example, has a semantical function different from that of 'rose' and 'red'. The function of the sentence is new with respect to the single words which are its parts. There are conventional rules which enable us to create such complex semantical products: for example, the rule according to which we can create sentences by means of the copula 'is' in Engish. Each resulting semantical product is then conventional in the sense that its semantical function does not depend on its outer physical shape.

The class of conventional semantical products can be divided, Ossowski claims, into two categories. To the first category belong those semantic products whose semantical function consists simply in naming or designating objects (these are called 'symbols' in Ossowski's terminology; they are pure denotations). To the second category of semantical products belong those products which mean something, divided by Ossowski into sentences, nominal phrases, and syncategoremata.

But now, a change of attitude can change the semantic function of a given expression. ${ }^{71}$ Semantical products with meanings are always signs of speech acts, something that is not true of symbols. Ossowski calls such products linguistic signs and he notes that they do not always have designations. The same linguistic sign can have a designation on one occasion but not on another, depending on the semantical attitude of the subject using it. So, by intentionally transforming a symbol into a linguistic sign, we can for example deprive it of its designation.

The distinction between naming and meaning (or between denotation and connotation) grows in importance when we move to consider the notion of truth. An expression is meaningful, Ossowski claims, under the following conditions: (1) the expression can be part of a true or false expression, and (2) all the parts of the expression have their normal semantical function in a given language. (It is an interesting fact that an expression in quotation marks does not fulfill the second condition. Thus, the name of a meaningful expression is not itself meaningful.)

A special class of meaningful expressions form sentences. These are special in the sense that they do not need to occur within any other expression, for sentences are true or

\footnotetext{
${ }^{71}$ Ossowski 1926, p. 34.
} 
false in themselves. Sentences are semantical products which are in this sense independent entities - they do not depend upon any other expressions for their meanings. In order to explain its semantical function, we do not need to appeal to any more complex product of which a sentence is a part. In this sense, sentences are the basic units of meaning. This also means that the basic semantical units are different from the basic units of meaning. The basic semantical units include the nominal expressions out of which we build sentences. This fact reflects simply that the meaning-function presents only one of the functions of semantical products.

Nominal expressions have a form of independence of their own. They are independent with regard to the function of naming or designating. This is because their semantical function can be explained by ostension - by pointing to that which they designate.

Neither of the two classes of independent semantical products distinguished by Ossowski can be reduced to the other. The attempt to unify these products by putting them all into one group rests on a mistake made by both Frege and Meinong. Both held that sentences must be taken in their function of naming or designating.

For Meinong, nominal expressions refer to objects and sentences refer to objectives. If a nominal expression refers to an object, then it communicates something about this object. And if a sentence tells us about some object, then it - or some constituent expression - must also refer to this object. So, according to Ossowski, Meinong identifies the semantical function of the sentence with the semantical function of the nominal expression. Meinong's assumption was that a sign is an object which communicates something about another object. According to Ossowski, however, what Meinong calls an objective ought properly to be referred to via a nominal expression of the form 'that the rose is red'. The latter, however, is not a sentence.

For Frege sentences refer to the True and the False as their objects. According to Ossowski, even though we can say about a sentence that it is true, this does not in the least imply that the sentence refers to the True. Properly understood, Ossowski holds, when we say of a sentence that it is true, we are asserting that it has the property of being true. When we say that the relation of reference holds between a sentence and the True, then we are asserting something quite different. If an expression refers to the True, then 
one cannot infer from this that the expression is true. Frege thus mixed up the function of referring or naming with the property of being true. 'Whoever states that a sentence refers, clearly understands the term "to refer" in some special way. ... Sentences have exclusively the properties of truth and falsity. ${ }^{, 72}$

\section{Final Remarks}

In the period between Bolzano's Theory of Science and Polish investigations of truth in the 1930s, theories of truthmakers and truthbearers undergo a transformation both in object and in method. Many philosophers in the analytic tradition after Frege appealed to sentences, to the 'institution of a common language', as an alternative to the Platonism of ideal meanings of the Bolzanian sort. ${ }^{73}$ The problem with such an approach is that it is not clear why, given the diversity and changeability of human languages, this appeal does not face objections parallel to those which had earlier confronted psychologism. The relativisation of truth to a given interpreted language within the framework of Tarski's semantical definition attempts to answer this question.

It has become a commonplace that Bolzano and Frege created the initial conditions for the development of logic in the modern sense. By defending a view of thoughts or propositions as ideal or abstract entities, they made possible a conception of propositions as entities capable of being manipulated in different ways in formal theories. But these theories faced difficulties with respect to the cognition of objective truths. How can we grasp ideal propositions existing in a realm outside space and time? To answer this question it was necessary to develop a theory of how meanings and logical objects are related to psychological or, more generally, to cognitive aspects of language usage - a theory of just the sort that we find in Husserl's Logical Investigations and also in a number of Polish thinkers who fell to a greater or lesser extent under the influence of this work. The achievements of Bolzano, Frege, and Tarski in securing the doctrine of the objectivity of truth which we all now take for granted were thus part of a larger historical process, which started with investigations of the objects of judging acts, which also take

\footnotetext{
${ }^{72}$ Ossowski 1926, p. 41.

${ }^{73}$ See, again, Dummett 1988, pp. 99f. of English edition.
} 
on the role of an objective measure or standard of truth by Brentano's followers. Gradually, it came to be divided into two lines of investigation: of truthmakers on the one hand, and of truthbearers on the other. Lotze, Bergmann, Brentano, and Stumpf, but also Marty, Meinong, Husserl, and Reinach as well as Twardowski and his students in Poland played a crucial role in both.

The separation of the two notions of proposition and state of affairs was first of all an important step on the road to overcoming psychologism. But it played an important role also in the separation of judging acts from complex concepts, and thus in the definitive overthrow of the combination theory. Through the abandonment of the immanentistic account of the objects of judgment, as well as through the clarification of the difference between ideal propositions and their linguistic expressions, the theory of true judgment was transformed from a theory of the immanent processes of correct thinking into a theory of the relations between the meaning and the objects of cognitive acts: from a theory of mental acts it became a theory of what these acts are about.

We have seen how the psychology of objective knowledge was replaced by the logical analysis of language and by the study of linguistic acts, and later on by the semantical analysis of language. It was not only Frege, Wittgenstein and Russell who made this replacement possible, but also thinkers in Poland. The latter are marked above all by their shared nominalistic sympathies, which led them to focus on sentential inscriptions - and we note that the sentence is taken by Tarski, too, as an inscription, a physical body that is determined in its makeup by the syntax of the pertinent language and is for this reason able to be apprehended with the semantical attitude. ${ }^{74}$ But Tarski's 1933 essay on the concept of truth is based also on a discovery of how it is possible to manipulate formally not only sentences or propositions but also certain special sorts of object-structures in the world to which these sentences or propositions correspond. In this respect, too, the separation of truthbearers and truthmakers effected in the wake of Bolzano and Brentano continues to influence contemporary investigations in logic and semantics.

\footnotetext{
${ }^{74}$ See Rojszczak 1998 and 1999.
} 


\section{Bibliography}

Ajdukiewicz, K. 1934 “Sprache und Sinn”, Erkenntnis 4, 100-38.

Ajdukiewicz, K. 1935 "Die syntaktische Konnexität” in Studia Philosophica, 1, 1-27.

Translated by H. Weber as "Syntactic Connexion" in S. McCall (ed.) Polish Logic, Oxford: Clarendon Press, 1967, 207-31.

Baumgartner, W. 1987 "Die Begründung von Wahrheit durch Evidenz. Der Beitrag Brentanos" in Gewissheit und Gewissen. Festschrift für Franz Wiedmann zum 60. Geburstag, Würzburg: Koenigshausen und Neumann, 93-116.

Bell, D. 1979 Frege's Theory of Judgment, Oxford: Clarendon Press.

Bergmann, J. 1879 Allgemeine Logik, I. Reine Logik, Berlin: Mittler.

Bolzano, B. 1837 Wissenschaftslehre, 4 vols., Sulzbach: Seidel. Translated by R. George, Theory of Science, Oxford: Blackwell, 1972.

Brentano, F. 1874 Psychologie vom empirischen Standpunkte, Leipzig: Duncker and Humblot. Second edition 1924. Translated by A. C. Rancurello, D. B. Terrell and L. L. MacAlister, Psychology from an Empirical Standpoint, London: Routledge, 1973.

Brentano, F. 1889 “Über den Begriff der Wahrheit”, as repr. in Brentano 1930, 3-29.

Brentano, F. 1928 Vom sinnlichen und noetischen Bewusstsein. Vol. III of Psychologie vom empirischen Standpunkt, Leipzig: Meiner. Translated by L. L. McAlister, Sensory and Noetic Consciousness, London: Routledge, 1981.

Brentano, F. 1930 Wahrheit und Evidenz, Leipzig: Meiner. Translated by R. M. Chisholm, I. Politzer, K. R. Fischer The True and the Evident, London: Routledge and Kegan Paul, 1966. 
Brentano, F. 1933 Kategorienlehre, Leipzig: Meiner. Translated by R. M. Chisholm and N. Guterman, The Theory of Categories, The Hague: Nijhoff, 1981.

Brentano, F. 1956 Die Lehre vom richtigen Urteil, Bern: Francke.

Brentano, F. 1982 Deskriptive Psychologie, Hamburg: Meiner. Translated by B. Müller as Descriptive Psychology, London/New York: Routledge, 1995.

Cantor, G. 1887/88 "Mitteilungen zur Lehre vom Transfiniten", as reprinted in Cantor 1966.

Cantor, G. 1895/97 "Beiträge zur Begründung der transfiniten Mengenlehre", as reprinted in Cantor 1966. Translated by P. E. B. Jourdain Contributions to the Founding of the Theory of Transfinite Numbers, New York: Dover, 1915.

Cantor, G 1966 Gesammelte Abhandlungen mathematischen und philosophischen Inhalts, Hildesheim: Olms.

Chrudzimski, Arkadiusz 2001 Intentionalitätstheorie beim frühen Brentano, Dordrecht: Kluwer.

Chrudzimski, Arkadiusz 2001a "Die Intentionalitätstheorie Anton Martys", Grazer Philosophische Studien, 62 (2001), 175-214.

Dummett, M. 1981 Frege, London: Duckworth.

Dummett, M. 1988 Ursprünge der analytischen Philosophie, Frankfurt: Suhrkamp. English version: Origins of Analytic Philosophy, London: Duckworth, Cambridge, MA: Harvard University Press, 1993. 
Frege, G. 1879 Begriffsschrift, Halle. Translated by S. Bauer-Mengelberg in J. van Heijenoort (ed.), From Frege to Gödel. A Source Book in Mathematical Logic, Cambridge MA: Harvard University Press, 1967.

Frege, Gottlieb 1884 Die Grundlagen der Arithmetik, Breslau: Wilhelm Koebner.

Husserl, E. 1894 "Intentionale Gegenstände" in Husserliana 22, The Hague: Nijhoff, $1979,303-348$.

Husserl, E. 1900/01 Logische Untersuchungen, Halle: Niemeyer. Translated by J. N. Findlay Logical Investigations, London: Routledge and Kegan Paul, 1970.

Kotarbinski, T. 1913 "Zagadnienie istnienia przyszonci” (The problem of the existence of the future), Przeglad Filozoficzny, 16, 74-92.

Kotarbinski, T. 1929 Elementy teorii poznania, logiki formalnej i metodologii nauk, Lvov. Cited according to the English translation, The Scientific Approach to the Theory of Knowledge, Oxford: Pergamon Press, Eng. trans. by O. Wojtasiewicz, 1966.

Kreiser, Lothar 2001 Gottlob Frege. Leben, Werk, Zeit, Hamburg: Felix Meiner.

Kusch, M. 1995 Psychologism. A Case Study in the Sociology of Philosophical knowledge, London/New York: Routledge.

Lesniewski, S. 1913 "Krytyka logicznej zasady wyczonego nrodku” (Critique of the principle of excluded middle), Przeglad Filozoficzny, 16, 315-52; Eng. trans. in Lesniewski 1992.

Lesniewski 1927 (includes Collected works p. 198) 
Lesniewski, S. 1992 Collected Works, S. J. Surma, J. T. Srzednicki and D. I. Barnett (eds.), 2 vols., Dordrecht/Boston/London: Kluwer.

Lotze, H. 1880 Logik: Drei Bücher vom Denken, vom Untersuchen, und vom Erkennen, 2nd ed. Leipzig: S. Hirzel.

Łukasiewicz, J. 1987 "On the Principle of the Excluded Middle", in History and Philosophy of Logic, 8, 67-69.

\section{Lukasiewicz 1907}

Łukasiewicz, J. 1910 "Über den Satz von Widerspruch bei Aristoteles”, Bulletin international de Académie des Sciences de Cracovie, Classe de philosophie, 15-38.

Lukasiewicz, J. 1913 "Logical Foundations of Probability Theory", as translated in Łukasiewicz, Selected Works, L. Borkowski (ed.), Amsterdam: North-Holland, 1970, 1663.

Marty, A. 1908 Untersuchungen zur Grundlegung der allgemeinen Grammatik und Sprachphilosophie, Halle: Niemeyer. New ed. 1976, Hildesheim/New York: Olms.

Meinong, A. 1899 “Über Gegenstände höherer Ordnung und deren Verhältnis zur inneren Wahrnehmung”, Zeitschrift für Psychologie und Physiologie der Sinnesorgane, 21, 182 272.

Meinong, A. 1902 Über Annahmen, Leipzig: Barth. Second edition 1910. Translated by J. Heanue as On Assumptions, Berkeley, Los Angeles, London: University of California Press, 1983.

Meinong, A. 1965 Philosophenbriefe, Graz: Akademische Druck- und Verlagsanstalt. 
Morscher, E. 1986 "Propositions and States of Affairs in Austrian Philosophy before Wittgenstein' in J. C. Nyiri (ed.), From Bolzano to Wittgenstein: The Tradition of Austrian Philosophy, Vienna: Hölder-Pichler-Tempsky, 75-85.

Mulligan, K. 1985 “'Wie die Sachen sich zueinander verhalten' Inside and Outside the Tractatus", Teoria 5, 145-174.

Mulligan, K. 19901990 "Husserl on States of Affairs in the Logical Investigations", Epistemologia, 12, 207-234.

Mulligan, K., Simons, P. M., and Smith, Barry 1984 "Truth-Makers", in Philosophy and Phenomenological Research, 44, 287-321.

Nuchelmans, G. 1973 Theories of the Proposition. Ancient and Medieval Conceptions of the Bearers of Truth and Falsity, Amsterdam and London: North-Holland.

Ossowska, M. 1928 “O pojeciu wyrazania” (On the concept of expression), Przeglad Filozoficzny, 12, 145-147.

Ossowska, M. 1931 "Slowa I mysli” (Words and thoughts), Przeglad Filozoficzny 34, 203-258.

Ossowski, S. "Analiza pojecia znaku” (An analysis of the concept of the sign), Przeglad Filozoficzny, 29, 29-56, fragments translated in J. Pelc (ed.), Semiotics in Poland 18941969, Dordrecht/Boston/London: Reidel, 164-177.

Pfeil, C. F. 1914 Der Einfluss Lotzes auf die logische Bewegung der Gegenwartet. Dargestellt am Begriff der Geltung und am Begriff der Wahrheit und des Apriori, Dissertation, Erlangen. 
Reinach, A. 1911 "Zur Theorie des negativen Urteils" as reprinted in Reinach 1989. Translated by Barry Smith 'On the Theory of the Negative Judgment', in B. Smith (ed.), Parts and Moments: Studies in Logic and Formal Ontology, Munich: Philosophia, 1982.

Reinach, A. 1913 "Die apriorischen Grundlagen des bürgerlichen Rechts" in Jahrbuch für Philosophie und phänomenologische Forschung, 1, 685-847. Translated by John Crosby, "The A Priori Foundations of the Civil Law", Aletheia, 3, 1983, 1-142.

Reinach, A. 1989 Sämtliche Werke: Kritische Ausgabe mit Kommentar, edited by K. Schuhmann and B. Smith, Munich: Philosophia.

Rojszczak, A. 1994 "Wahrheit und Evidenz bei Franz Brentano", in: Brentano Studien, 5, 187-218.

Rojszczak, A.1997 “Od sądów do zdań. Nośnik prawdy a obiektywizacja wiedzy”, Filozofia Nauki, 2 (18). Translation forthcoming as "From the Act of Judging to the Sentence. The Problem of Truth-Bearers and the Objectivisation of Knowledge", in Jadacki, J. J. and Paśniczek, J. (eds.), The Lvov-Warsaw School: Second Generation, Boston: Rodopi.

Rojszczak, A. 1998 “Truth-Bearers from Twardowski to Tarski”, in K. Kijania-Placek, and J. Woleński (eds.), The Lvov-Warsaw School and Contemporary Philosophy, Dordrecht: Kluwer, 73-84.

Rojszczak A. 1999 "Why Should a Physical Object Take on the Role of Truth-Bearer?" in E. Köhler and J. Woleński (eds.), Alfred Tarski and the Vienna Circle. Dordrecht: Kluwer, 115-125.

Rojszczak A. and Smith, B. 2001 "Urteilstheorien und Sachverhalte" in Satz und Sachverhalt, edited by O. Neumayer, Sankt Augustin: Academia Verlag, 9-72. 
Rojszczak A. and Smith, B. (in press) "Theories of Judgment”, in The Cambridge History of Philosophy 1870-1914, edited by T. Baldwin, Cambridge: Cambridge University Press.

Schaar, M. van der 1991 G. F. Stout's Theory of Judgment and Proposition, Dissertation, University of Leiden.

Schuhmann, K. and Smith, Barry 1987 "Questions: An Essay in Daubertian Phenomenology" in Philosophy and Phenomenological Research, 47, 353-84.

Schuhmann, K. 1998 “Johannes Daubert's Theory of Judgment” in R. Poli (ed.) The Brentano Puzzle, Aldershot/Hants/Brookfield: Ashgate, 179-197.

Simons, P. M. 1982 “On Understanding Leśniewski”, History and Philosophy of Logic, 3, 165-191. Reprinted in P. M. Simons Philosophy and Logic in Central Europe from Bolzano to Tarski, Dordrecht: Kluwer, 1992, 227-258.

Simons, P. M. 1993 "Nominalism in Poland", in: F. Coniglione, R. Poli and J. Wolenski (eds.), Polish Scientific Philosophy: The Lvov-Warsaw School, Amsterdam: Rodopi, 207-231.

Sluga, H. 1980 Gottlob Frege, London: Routledge.

Smith, Barry 1978 “An Essay in Formal Ontology” in Grazer Philosophische Studien, 6, $39-62$.

Smith, Barry 1987 "On the Cognition of States of Affairs" in K. Mulligan (ed.) Speech Act and Sachverhalt: Reinach and the Foundations of Realist Phenomenology, Dordrecht/Boston/Lancaster: Nijhoff, 189-225.

Smith, Barry 1989 "On The Origins of Analytical Philosophy [Review of Dummett 1988]" in: Grazer Philosophische Studien, 35,153-173. 
Smith, Barry 1989a "Logic and Formal Ontology", in J. N. Mohanty and W. McKenna (eds.), Husserl's Phenomenology: A Textbook, Lanham: University Press of America, 1989, 29-67.

Smith, Barry 1990 "Towards a History of Speech Act Theory" in A. Burckhardt (ed.) Speech Acts, Meanings, and Intentions: Critical Approaches to the Philosophy of John R. Searle, Berlin, New York: de Gruyter, 29-61.

Smith, Barry 1992 "Sachverhalt" in J. Ritter and K. Grünberg (ed.), Historisches Wörterbuch der Philosohie, Basel: Schwabe, vol. 8, 1102-1113.

Smith, Barry 1992a "Characteristica Universalis", in K. Mulligan, ed., Language, Truth and Ontology (Philosophical Studies Series), Dordrecht/Boston/London: Kluwer, 1992, 48-77.

Smith, Barry 1994 Austrian Philosophy, Chicago: Open Court.

Smith, Barry 1999 "Truthmaker Realism”, Australasian Journal of Philosophy, 77, 274 291.

Smith, Barry (ed.) 1982 Parts and Moments. Studies in Logic and Formal Ontology, Munich: Philosophia.

Stumpf, C. 1907 "Erscheinungen und psychische Funktionen" in Abhandlungen der Königlichen Preussischen Akademie der Wissenschaften, phil.-hist. K1., 4.

Stumpf, C. 1907a "Zur Einteilung der Wissenschaften” in Abhandlungen der Königlichen Preussischen Akademie der Wissenschaften, phil-hist. Kl., 4. 
Tarksi, A. 1933 "Pojecie prawdy w jezykach nauk dedukcyjnych", Prace Towarzystwa Naukowego Warszawskiego (Wydzial III nauk matematyczno-fizycznych), 34. German revised version: "Der Wahrheitsbegriff in den formalisierten Sprachen", Studia Philosophica 11936, 261-405. English translation of German version with supplementary comments: "The Concept of Truth in Formalized Languages" in A. Tarski, 1956.

Tarski, A. 1956 Logic, Semantics, Metamathematics: Papers from 1923 to 1938 (translation by J. H. Woodger), Oxford: Clarendon Press.

Twardowski, K. 1894 Zur Lehre vom Inhalt und Gegenstand der Vorstellungen: Eine psychologische Untersuchung, Wien: Hölder. Translated by R. Grossmann as On the Content and Object of Presentation, The Hague: Nijhoff, 1977.

Twardowski, K. 1902 “Über relative Wahrheit”, Archiv für systematische Philosophie, 8, 415-447.

Twardowski, K. 1912 "Actions and Products. Comments on the Border Area of Psychology, Grammar and Logic", as repr. in Twardowski, On Actions, Products And Other Topics In Philosophy, J. Brandl and Jan Wolenski (eds.), Amsterdam: Rodopi, 1999.

Willard, D. 1984 Logic and the Objectivity of Knowledge, Athens, Ohio: University of Ohio Press.

Witasek, S. 1908 Grundlinien der Psychologie, Leipzig: Dürr.

Wittgenstein, L. 1921 Tractatus Logico-Philosophicus, first published in Annalen der Naturphilosophie 14, 185-262. Translated by D. F. Pears and B. F. McGuinness, London: Routledge, 1961. 
Woleński, J. 1989 Logic and Philosophy in the Lvov-Warsaw School, Dordrecht/Boston/Lancaster: Kluwer.

Woleński, J. 1998 "Theories of Truth in Austrian Philosophy”, forthcoming in Czarnecki T. (ed.) Rationalistic Epistemology, (Reports on Philosophy, 18), Cracow: Jagiellonian University.

Woleński, J. 1998/99 “The Content/Object Distinction” forthcoming in: Brentano Studien, 8 ,

Woleński, J. and Simons, P. M. 1989 "De Veritate: Austro-Polish Contributions to the Theory of Truth from Brentano to Tarski" in K. Szaniawski (ed.) The Vienna Circle and the Lvov-Warsaw School, Dordrecht/Boston/London: Kluwer. 